Л.В. Мороз, М.О. Шостацька, О.А. Гнатюк

Вінницький національний медичний університет імені М.І. Пирогова

\title{
Адаптаційні можливості та реактивність організму пацієнтів похилого віку на фоні гострої кишкової інфекції, спричиненої умовно-патогенними мікроорганізмами, з урахуванням етіологічного фактора
}

Мета - оцінити адаптаційні можливості та реактивність організму пацієнтів похилого віку на фоні гострої кишкової інфекції (ГКІ), спричиненої умовно-патогенними мікроорганізмами (УПМ), з урахуванням провідного етіологічного фактора. Об'єкт і методи дослідження. Проаналізовано дані історій хвороби 46 пацієнтів похилого віку з ГКІ, спричиненими УПМ. На основі виділеного збудника сформовано три групи пацієнтів: 1-ша ( $n=26)$ - ГКІ, спричинена ентеропатогенною кишковою паличкою, 2-га $(n=6)$ - представниками родини Pseudomonadaceae, 3-тя (n=14) - Staphylococcus aureus. Для оцінки адаптаційних можливостей організму використовували індекс адаптації, лейкоцитарний індекс, індекс співвідношення нейтрофілів та лімфоцитів, індекс співвідношення нейтрофілів та моноцитів. Результати. У пацієнтів 2-ї групи інтоксикаційний синдром мав переважно інфекційний генез, спостерігали ознаки напруження гуморальної ланки імунітету та посилення факторів неспецифічної реактивності. УЗ-й групі переважали аутоімунні чинники формування інтоксикаційного синдрому, спостерігали ознаки незавершеності фагоцитозу та гіперчутливості сповільненого типу. Висновки. Доведено достовірні відмінності адаптаційних можливостей та реактивності організму пацієнтів похилого віку на фоні ГКІ, спричиненої УПМ, з урахуванням провідного етіологічного фактора.

Ключові слова: пацієнти похилого віку, гостра кишкова інфекція, умовно-патогенна флора, реактивність організму, адаптаційні можливості.

\section{Вступ}

Досягнення сучасної медицини, спрямовані на покращення якості життя та продовження його тривалості, пов'язані з ростом частки населення похилого віку. Старіння - біологічний руйнівний процес, який неминуче розвивається з віком та призводить до обмеження адаптаційних можливостей організму і розвитку вікових патологій. Вагомою проблемою охорони здоров'я є підтримка здорового способу життя людей похилого віку, лікування та профілактика захворювань, пов'язаних із віковими особливостями організму (Моложавая О.С. и соавт., 2016а). Процес старіння пов'язаний зі структурно-функціональними змінами на молекулярному, клітинному, органному та системному рівнях, що призводить до зниження адаптаційних реакцій та реактивності організму пацієнтів похилого віку і супроводжується тяжчим перебігом усіх хвороб (Паршиков И.А. и соавт., 2013; Mallory E.K. et al., 2018).

У численних дослідженнях продемонстровано зв'язок адаптаційних реакцій організму з особливостями перебігу та клініколабораторними показниками при патологіях респіраторного тракту, різних клінічних формах туберкульозу та хворобах шлунково-кишкового тракту (Егшатян Л.В. и соавт, 2015; Радченко О.М., Пилипів Л.І., 2016; Shondelmyer K. et al., 2018). Актуальним $€$ визначення адаптаційних реакцій та реактивності організму у пацієнтів похилого віку на фоні гострої кишкової інфекції (ГКІ), спричиненої умовно-патогенними мікроорганізмами (УПМ), які вивчені недостатньо. У клінічних умовах для комплексної діагностики адаптаційних реакцій перспективним $€$ використання інтегральних гематологічних показників. Окремі параметри лейкоцитарної формули не дають цілісної уяви про реакцію системи крові та реактивність організму, більш інформативним вважають визначення інтегральних гематологічних показників (Радченко О.М., Пилипів Л.І., 2016). Застосування лейкоцитарних індексів із високим ступенем достовірності допомагає в діагностиці та прогнозуванні змін стану організму.
Доведено, що вікові зміни організму пов'язані з низькою варіабельністю мікроорганізмів та змінами їх співвідношення (Моложавая О.С. и соавт., 2016б; Obata Y., Pachnis V., 2016; Yoo B.В., Mazmanian S.K., 2017). Важливо враховувати можливу втрату толерантності та розвиток резистентності до власних мікроорганізмів серед пацієнтів старшої вікової групи. Встановлено, що порушення мікробіоценозу пов'язані зі змінами імунної системи, що додатково підвищує ризик захворюваності та їх ускладнений перебіг (Mandal S. et al., 2015). Зміни імунного статусу пацієнтів похилого віку в цілому та порушення функціонування в лімфоїдній системі кишечнику зокрема асоційовані з вищою частотою ГКІ, спричинених УПМ.

Зважаючи на високу частоту ГKІ, спричинених УПМ, у пацієнтів похилого віку та пов'язаних із ними дезадаптаційних порушень, визначення інтегральних гематологічних індексів як предикторів оцінки тяжкості ендогенної інтоксикації та активності запального процесу є актуальним і потребує подальшого вивчення.

Мета - оцінити адаптаційні можливості та реактивність організму на основі розрахунку гематологічних інтегральних показників у пацієнтів похилого віку на фоні ГКІ, спричиненої УПМ, з урахуванням провідного етіологічного фактора.

\section{Об'єкт і методи дослідження}

Проведено ретроспективний аналіз історій хвороби пацієнтів похилого віку з ГКІ, спричиненими УПМ, які перебували на стаціонарному лікуванні в інфекційному відділенні Вінницької центральної районної лікарні в період 2008-2018рр. У досліджувану групу включено 46 осіб $(11(23,91 \%)$ чоловіків та 35 (76,09\%) жінок;

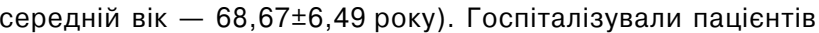
на 3,63 $\pm 3,88$ добу захворювання. Усі лікувально-діагностичні процедури здійснювали за інформованою згодою пацієнтів.

Бактеріологічне підтвердження діагнозу отримано в усіх обстежених. Найчастішим етіологічним чинником ГКІ були ентеропатогенні кишкові палички - 26 (56,52\%); представники родини Pseudomonadaceae виділено у 6 (13,04\%), Staphylococcus aure- 
us - у 14 (30,43\%) пацієнтів. Серед ентеропатогенних кишкових паличок найчастіше виявлено бактерії роду Proteus: Proteus mirabilis - у 11 (23,91\%), Proteus vulgaris - у 2 (4,35\%) пацієнтів. Citrobacter freundii виділено у $5(10,87 \%)$ пацієнтів, бактерії роду Klebsiella - y 8 (17,39\%): Enterobacter aerogenes - y $5(10,87 \%)$ та Klebsiella pneumoniae - у $3(6,52 \%)$ пацієнтів. На основі виділеного збудника усіх пацієнтів розподілили на три групи: до 1-ї включено пацієнтів із ГKІ, спричиненими ентеропатогенними кишковими паличками, до 2-ї - представниками родини Pseudomonadaceae, до 3-ї - Staphylococcus aureus.

Для оцінки адаптаційних можливостей організму використовували індекс адаптації (IA) за А.X. Гаркави, згідно з яким виділяли реакції тренування, спокійної активації, напруженої активації та стресу. Серед показників неспецифічної реактивності також оцінено лейкоцитарний індекс (ЛІ), індекс співвідношення нейтрофілів і лімфоцитів (ІСНЛ) та індекс співвідношення нейтрофілів та моноцитів (ICHM). Розрахунок інтегральних гематологічних показників виконували усім пацієнтам, додатково проводили міжгруповий аналіз отриманих показників з урахування етіологічного чинника ГКІ.

Відповідно до тесту Колмогорова - Смірнова розподіл досліджуваної вибірки достовірно відрізнявся від нормального $(p>0,05)$. Для оцінки різниці у незалежних сукупностях застосовували непараметричний критерій Краскела - Уолліса. Вірогідність безпомилкового прогнозу встановлювали при $p \leqslant 0,05$. Отримані результати наведені у вигляді середнього арифметичного \pm середнього квадратичного (M $\pm \mathrm{SD})$. Статистичний аналіз отриманих результатів проведений за допомогою програми «Statistica 13».

\section{Результати та їх обговорення}

Згідно з оцінкою індексів неспецифічної реактивності організму у пацієнтів, середній рівень ІА становив $0,39 \pm 0,12$ та відповідав фізіологічним процесам резистентності організму (таблиця). У більшості пацієнтів - 34 (73,91\%) - спостерігали фізіологічні реакції тренування, у решти $12(26,09 \%)$ - патологічні реакції: у $7(15,22 \%)$ - патологічні реакції стресу та у $5(10,87 \%)$ - реакції спокійної активації. Середній рівень ІА у пацієнтів 1-ї групи становив $0,37 \pm 0,09$, що свідчило про формування фізіологічних реакцій тренування. У більшості пацієнтів групи - 21 (80,77\%) - ІА відповідав референтним значенням, у 2 (7,69\%) - спостерігали ознаки спокійної активації, у $3(11,54 \%)$ - патологічні реакції стресу.

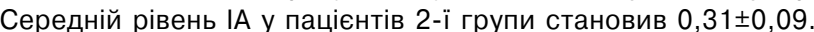
У $3(50,0 \%)$ обстежених виявлено патологічні реакції стресу, у $3(50,0 \%)-$ фізіологічні реакції тренування. У пацієнтів 3-ї групи середній рівень IA становив $0,45 \pm 0,15$. У більшості пацієнтів $10(71,43 \%)$ - спостерігали фізіологічні реакції тренування, у $1(7,14 \%)$ - патологічні реакції стресу, у $3(21,43 \%)$ - реакції спокійної активації. При порівнянні середніх рівнів ІА у групах пацієнтів з урахуванням провідного етіологічного чинника ГК встановлено достовірну відмінність між показниками $(p=0,02)$ (рис. 1). Аналізуючи частоту патологічних реакцій стресу в досліджуваних групах, доведено наявність статистично значущої різниці $(p=0,04)$, що свідчить про високу поширеність цього типу реакцій у пацієнтів 2-ї групи. Таким чином, у пацієнтів 2-ї групи переважали інфекційні фактори інтоксикаційного синдрому, а в 3-й групі - аутоімунні чинники.

Аналізуючи процеси неспецифічної та специфічної резистентності організму у пацієнтів, виявлено, що середній рівень ICHЛ

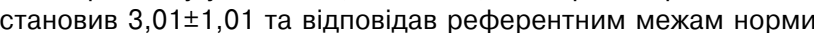
у більшості - $25(54,35 \%)$ пацієнтів. Порушення резистентності зареєстровано у 21 (45,65\%), підвищення ICHЛ - у 17 (36,96\%), зниження - у 4 (8,69\%) пацієнтів. Середній рівень ICHЛ у пацієн-

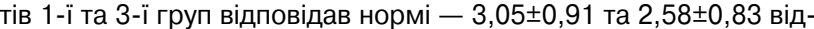
повідно. У пацієнтів 2-ї групи спостерігали підвищення ICHЛ $3,87 \pm 1,36$, що свідчить про переважання інфекційного генезу у розвитку ендогенної інтоксикації. При міжгруповому аналіз середніх рівнів ICHЛ у групах пацієнтів встановлено достовірну відмінність між показниками ( $p=0,01)$ (рис. 2). У більшості пацієнтів 1-ї та 3-ї груп - 15 (57,69\%) та 9 (64,28\%) відповідно - і лише в $1(16,67 \%)$ - 2-ї групи порушення резистентності не спостерігали; достовірної відмінності не встановлено $(p=0,13)$. Натомість у більшості пацієнтів 2-ї - 5 (83,33\%), а також 10 (38,46\%) - 1-ї та 2 (14,29\%) - 2-ї групи спостерігали підвищення ІСНЛ; встанов-
Таблиця. Порівняльна характеристика індексів неспецифічної реактивності у пацієнтів похилого віку на фоні ГKІ з урахуванням провідного етіологічного фактора, $\mathrm{n}(\%)$

\begin{tabular}{|c|c|c|c|c|}
\hline \multirow{2}{*}{$\begin{array}{l}\text { Гематологічний } \\
\text { індекс }\end{array}$} & \multicolumn{3}{|c|}{ Група } & \multirow[b]{2}{*}{ p } \\
\hline & 1-ша & 2-га & 3-тя & \\
\hline IA & $0,37 \pm 0,09$ & $0,31 \pm 0,09$ & $0,45 \pm 0,15$ & $0,02^{*}$ \\
\hline$<0,3$ & $3(11,54)$ & $3(50,0)$ & $1(7,14)$ & $0,04^{\star}$ \\
\hline $0,3-0,5$ & $21(80,77)$ & $3(50,0)$ & $10(71,43)$ & 0,3 \\
\hline $0,5-0,7$ & $2(7,69)$ & - & $3(21,43)$ & 0,28 \\
\hline IСНЛ & $3,05 \pm 0,91$ & $3,87 \pm 1,36$ & $2,58 \pm 0,83$ & $0,01^{*}$ \\
\hline$<1,82$ & $1(3,85)$ & - & $3(21,43)$ & 0,13 \\
\hline $1,82-3,12$ & $15(57,69)$ & $1(16,67)$ & $9(64,28)$ & 0,13 \\
\hline$>3,12$ & $10(38,46)$ & $5(83,33)$ & $2(14,29)$ & $0,01^{*}$ \\
\hline ICHM & $32,22 \pm 14,01$ & $45,76 \pm 25,81$ & $33,94 \pm 23,01$ & 0,23 \\
\hline $10,52-13,14$ & $1(3,85)$ & - & $3(21,43)$ & 0,13 \\
\hline$>13,14$ & $25(96,15)$ & $6(100,0)$ & $11(78,57)$ & 0,13 \\
\hline ЛІ & $0,71 \pm 0,17$ & $0,55 \pm 0,07$ & $0,81 \pm 0,19$ & $0,004^{\star}$ \\
\hline$<0,79$ & $20(76,92)$ & $6(100,0)$ & $6(42,86)$ & $0,02^{\star}$ \\
\hline $0,79-1,08$ & $5(19,23)$ & - & $6(42,86)$ & 0,09 \\
\hline$>1,08$ & $1(3,85)$ & - & $2(14,28)$ & 0,36 \\
\hline
\end{tabular}

*Встановлено вірогідність безпомилкового прогнозу при р<0,05.

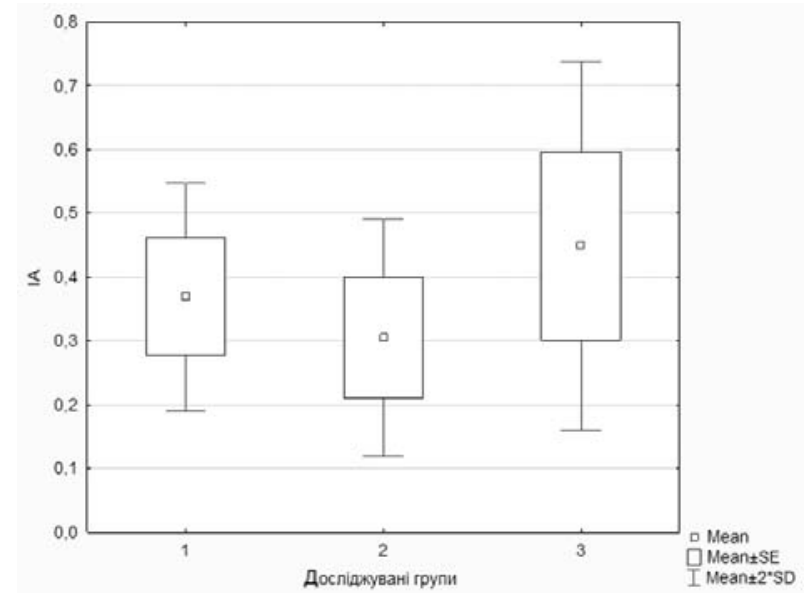

Рис. 1. Порівняльна характеристика показників ІА у пацієнтів похилого віку 3 ГKI з урахуванням провідного етіологічного фактора

лено статистично значущу різницю $(p=0,01)$. Отже, у пацієнтів 2-ї групи переважали інфекційні фактори у формуванні інтоксикаційного синдрому та спостерігали ознаки напруженості гуморальної ланки імунітету. Порушення неспецифічної резистентності організму, що зумовлювало зниження ICHЛ, відзначено у 1 (3,85\%) пацієнта 1 -ї та у $3(21,43 \%)-3$-ї групи, у 2-й групі цих проявів не виявлено; достовірної відмінності не встановлено $(p=0,13)$.

Середній рівень ICHM становив $34,51 \pm 18,87$, що значно перевищувало показники референтних значень як в цілому по вибірці,

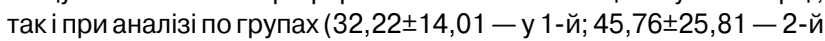
та 33,94 $\pm 23,01-3-$ й); достовірної відмінності не встановлено ( $p=0,23)$ (рис. 3). у $42(91,30 \%)$ пацієнтів $(25(96,15 \%)-1-і ̈$, $6(100,0 \%)-2$-ї та $11(78,57 \%)$ - 3-ї групи) спостерігали ознаки активізації моноцитарно-макрофагальної системи та підвищення фагоцитарної активності макрофагів; достовірної відмінності не встановлено $(p=0,13)$. Лише у $4(8,70 \%)$ пацієнтів ІСНМ відповідав межам референтної норми - у 1 (3,85\%) 1 -ї та у $3(21,43 \%)-$ 3-ї групи; достовірної відмінності не виявлено $(p=0,13)$.

Середній рівень ЛІ по вибірці становив 0,72 0 0,18 та відповідав референтним показникам норми. У пацієнтів 2-ї групи середній рівень ЛІ найнижчий $-0,55 \pm 0,07$, у пацієнтів 1 -ї групи - теж нижче референтних меж $-0,71 \pm 0,17$, у 3 -й - відповідав нормі $(0,81 \pm 0,19)$; встановлено достовірну відмінність показників ( $p=0,004)$ (рис. 4). Зниження ЛІ спостерігали у $32(69,57 \%)$ пацієнтів: в $6(100,0 \%)-2-i, 20(76,92 \%)-1$-ї та $6(42,86 \%)-3$-і групи; встановлено достовірну відмінність $(p=0,02)$. Таким чином, у більшості пацієнтів превалювали інфекційні чинники ендогенної інтоксикації. Збереження ЛІ в межах референтних значень спостерігали у 11 (23,91\%) пацієнтів: у $6(42,86 \%)$ - 3-їта 5 (19,23\%)1-ї групи; у пацієнтів 2-ї групи не спостерігали (достовірної відмінності не встановлено - p=0,09). Підвищення ЛІ, що свідчило про активність імунних механізмів у формуванні ендогенної інток- 


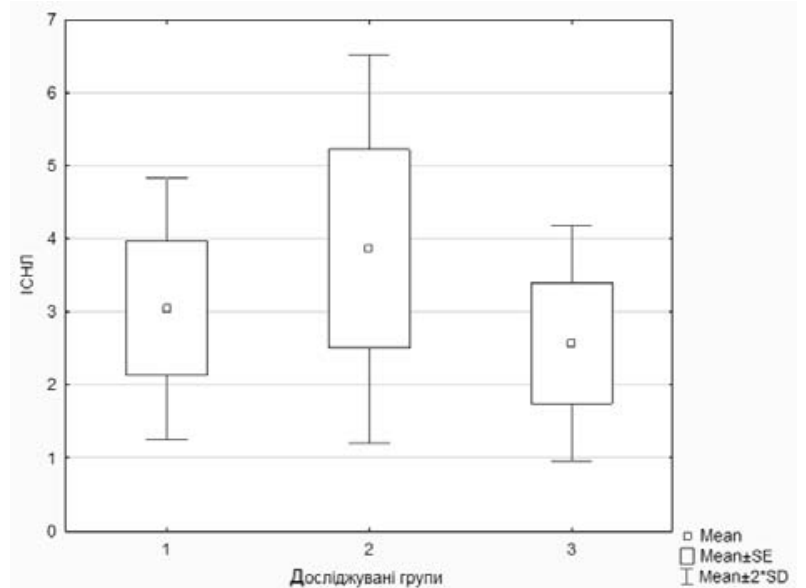

Рис. 2. Порівняльна характеристика ICHЛ у групах пацієнтів похилого віку з ГKІ з урахуванням провідного етіологічного фактора

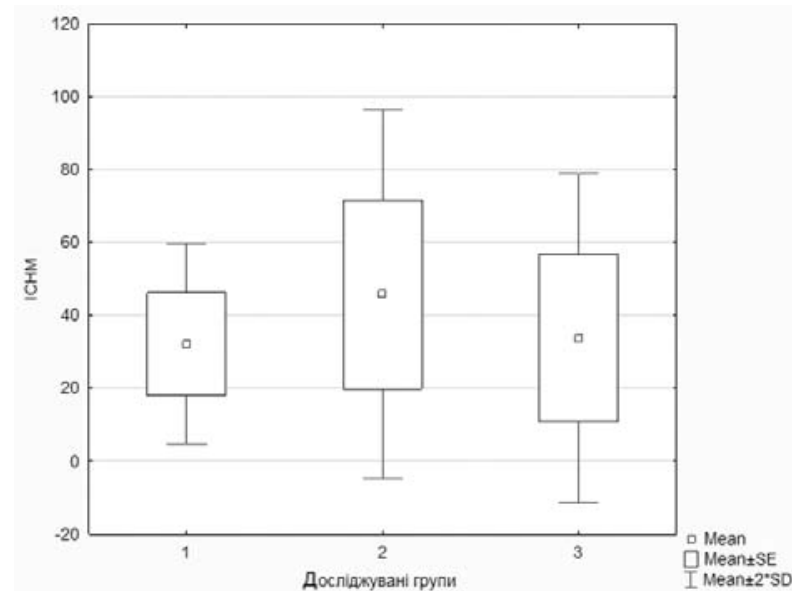

Рис. 3. Порівняльна характеристика ICHМ у групах пацієнтів похилого віку з ГKІ з урахуванням провідного етіологічного фактора

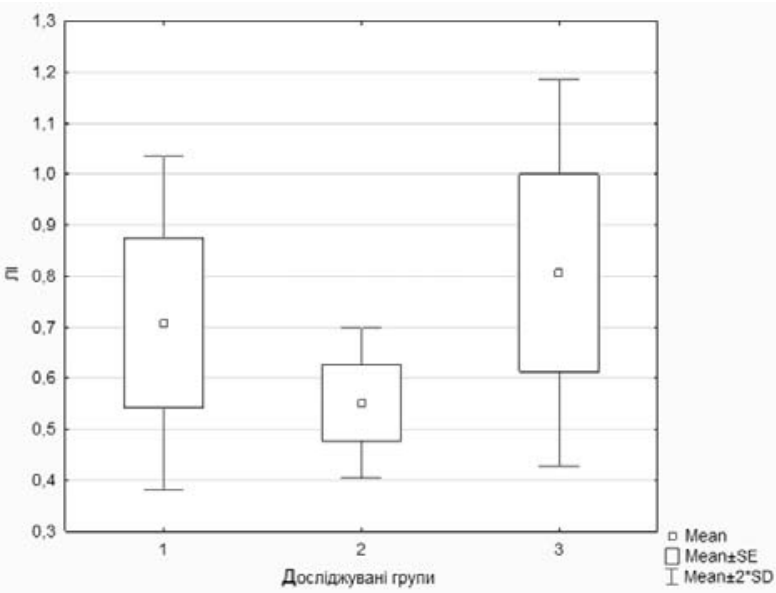

Рис. 4. Порівняльна характеристика ЛІ у групах пацієнтів похилого віку з ГKІ з урахуванням провідного етіологічного фактора

сикації, відзначали у 3 (6,52\%) пацієнтів: 2 (14,28\%) - 3-ї та $1(3,85 \%)$ - 1-ї групи; достовірної відмінності не встановлено $(p=0,36)$. Підвищення ЛІ зумовлено незавершеністю фагоцитозу та є проявом гіперчутливості сповільненого типу.

\section{Висновки}

1. На основі розрахунку гематологічних інтегральних показників доведено відмінності адаптаційних можливостей та реактивності організму пацієнтів похилого віку на фоні ГКІ, спричиненої УПМ, з урахуванням провідного етіологічного фактора.
2. За всіма досліджуваними параметрами у пацієнтів 2-ї групи з ГKІ, спричиненою представниками родини Pseudomonadaceae, інтоксикаційний синдром мав переважно інфекційний генез, спостерігали ознаки напруження гуморальної ланки імунітету та посилення факторів неспецифічної реактивності організму.

3. У 3-й групі, де основним етіологічним збудником був Staphylococcus aureus, переважали аутоімунні чинники формування інтоксикаційного синдрому, виявляли ознаки незавершеності фагоцитозу та гіперчутливості сповільненого типу.

\section{Список використаної літератури}

Егшатян Л.В., Ткачева О.Н., Кафарская Л.И. и др. (2015) Изменения кишечной микрофлоры, ассоциированные с возрастом и образом жизни. Ожирение и метаболизм, 12(2): 3-9.

Моложавая О.С., Ивахнюк Т.В., Макаренко А.Н. (2016а) Влияние физиологического старения организма на микрофлору желудочно-кишечного тракта. Акт. пробл. сучасної медицини, 16(1): 304-313.

Моложавая О.С., Ивахнюк Т.В., Макаренко А.Н., Брозь Р.В. (2016б) Функции кишечной микрофлоры организма в норме и при патологии. Акт. пробл. сучасної медицини, Т. 16, 4(56): 333-340.

Паршиков И.А., Полтавцев А.М., Осьмак Г.Ж. (2013) Влияние старения на микрофлору кишечника (литературный обзор). Молодой ученый, 11: 201-204.

Радченко О.М., Пилипів Л.І. (2016) Гематологічні параметри у хворих на хронічне обструктивне захворювання легень 3 дистресом та еустресом. Акт. пробл. сучасної медицини, Т. 16, 4(56): 175-179.

Mallory E.K., Acharya A., Rensi S.E. et al. (2018) Chemical reaction vector embeddings: towards predicting drug metabolism in the human gut microbiome. Pac. Symp. Biocomput., 23: 56-67.

Mandal S., Van Treuren W., White R.A. et al. (2015) Analysis of composition of microbiomes: a novel method for studying microbial composition. Microb. Ecol. Health Dis., 26: 27663.

Obata Y., Pachnis V. (2016) The effect of microbiota and the immune system on the development and organization of the enteric nervous system. Gastroenterol., 151(5): 836-844.

Shondelmyer K., Knight R., Sanivarapu A. et al. (2018) Ancient thali diet: gut microbiota, immunity, and health. Yale J. Biol. Med., 91(2): 177-184.

Yoo B.B., Mazmanian S.K. (2017) The Enteric network: interactions between the immune and nervous systems of the gut. Immunity, 46(6): 910-926.

\section{Адаптационные возможности}

и реактивность организма пациентов

пожилого возраста на фоне

острой кишечной инфекции, обусловленной условно-патогенными микроорганизмами, с учетом этиологического фактора

\section{Л.В. Мороз, М.А. Шостацкая, Е.А. Гнатюк}

Резюме. Цель - оценить адаптационные возможности и реактивность организма пациентов пожилого возраста на фоне острой кишечной инфекции (ОКИ), вызванной условно-патогенными микроорганизмами (УПМ), с учетом ведущего этиологического фактора. Объект и методы исследования. Проанализированы данные историй болезни 46 пациентов пожилого возраста с ОКИ, вызванными УПМ. На основании выделенного возбудителя сформировано три группы пациентов: 1-я(n=26) - ОКИ, вызванные энтеропатогенными кишечными палочками, 2-я $(n=6)$ - представителями семейства Pseudomonadaceae, 3-я $(n=14)$ - Staphylococcus aureus. Для оценки адаптационных возможностей организма использовали индекс адаптации, лейкоцитарный индекс, индекс соотношения нейтрофилов и лимфоцитов, индекс соотношения нейтрофилов и моноцитов. Результаты. Упациентов 2-й группы интоксикационный синдром имел преимущественно инфекционный генез, отмечены признаки напряжения гуморальной цепи иммунитета и усиление факторов неспецифической реактивности организма. В 3-й группе преобладали аутоиммунные факторы формирования интоксикационного синдрома, отмечены признаки незавершенности фагоцитоза и гиперчувствительности замедленного типа. Выводы. Доказано достоверное отличие адаптационных возможностей и реактивности организма пациентов пожилого возраста на фоне ОКИ, вызванной УПМ, с учетом ведущего этиологического фактора.

Ключевые слова: пациенты пожилого возраста, острая кишечная инфекция, условно-патогенная флора, реактивность организма, адаптационные возможности. 


\section{Adaptation possibilities and reactivity in elderly patients against acute intestinal infection caused by nonpathogenic microorganisms, taking into account the leading etiological factor \\ L.V. Moroz, M. O. Shostatska, O.A. Hnatiuk}

Summary. Objective - to evaluate the adaptive capacity and reactivity in elderly patients with acute intestinal infection (All) caused by nonpathogenic microorganisms (NM), taking into account the leading etiological factor. Object and research methods. The data of 46 elderly patients with All caused by NM were analyzed. On the basis of the selected pathogen 3 groups of patients were formed: $1^{\text {st }}(n=26)$ - with All caused by enteropathogenic microorganisms, $2^{\text {nd }}(n=6)$ - representatives of the Pseudomonadaceae, $3^{\text {rd }}(n=14)$ - Staphylococcus aureus. The adaptation index leukocyte index, the neutrophil-to-lymphocyte ratio, the neutrophil-tomonocyte ratio were used to evaluate the adaptive capacity of the organism. Results. In patients of the $2^{\text {nd }}$ group intoxication syndrome has mainly infectious genesis, there were signs of tension of the humoral level of immunity and increased factors of nonspecific reactivity. In the $3^{\text {rd }}$ group, autoimmune factors of the formation of intoxication syndrome predominated, signs of incompleteness of phagocytosis and delayed type hypersensitivity were observed. Conclusions. Significant differences in the adaptive capacity and reactivity of the elderly patients with All caused by NM have been proved, taking into account the leading etiological factor.

Key words: elderly patients, acute intestinal infection, nonpathogenic microorganism, reactivity, adaptive capacity.

\section{Адреса для листування:}

Шостацька Марія Олександрівна

21000, Вінниця, вул. Пирогова, 56

Вінницький національний медичний

університет імені М.І. Пирогова,

кафедра інфекційних хвороб з курсом епідеміології

E-mail: mariashostatska@gmail.com

Одержано 25.09.2019

\section{РЕФЕРАТИВНА ІНФОРМАЦІЯ}

\section{Хронобіологія сну та синаптичні ритми організму \\ Синаптична активність та добові ритми}

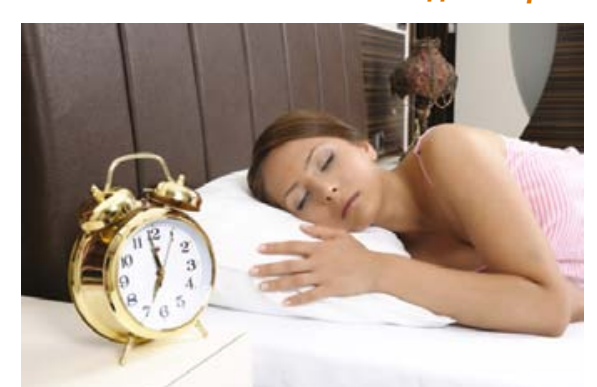

Відомо,щофосфорилювання білків, зумовленециркадними біоритмами є ключовим механізмом часового розподілу періодичності біологічних процесів організму протягом доби. Водночас фосфорилювання окремих білків у тканинахголовного мозку корелює з циклами сон неспання, які, усвою чергу, зумовлені циркадними змінами. Локальні процеси нейронального фосфорилювання відіграють основну роль у регуляції синаптичних функцій, забезпечуючи швидку модуляцію активності протеїнів. Останнє, у свою чергу, дозволяє динамічно масштабувати інтенсивність синаптичної передачі сигналів у відповідь на циркадні ритми чи стимули, зумовлені зміною циклу сон неспання.

Унещодавно проведеномудослідженні, результати якого представлені хронобіологами медичного факультету Інституту медичної психології Університету Людвіга Максиміліана в Мюнхені (Institute of Medical Psychology, Faculty of Medicine, Ludwig Maximilian University of Munich), Німеччина, а також науковими співробітниками $\mathrm{lH}$ ституту фармакології та токсикології Цюріхського університету (Institute of Pharmacology and Toxicology, University of Zurich), Швейцарія, було системно обґрунтовано біологічне значення циклу сон - неспання у фосфорилюванні протеїнів синаптичного компартменту для подальшої регуляції ефективності міжнейронної передачі численних функціональних мереж головного мозку. Підсумкові результати дослідження опубліковано у двох статтях у виданні «Science» 11 жовтня $2019 \mathrm{p}$.

\section{Цикл сон - неспання у часовій регуляції}

синаптичної активності

Внутрішні біоритми контролюють переважну більшість фізіологічних процесів в організмі, відповідно до щоденних повторюваних змін довкілля, таких як чергування дня та ночі. Молекулярні механізми циркадних ритмів модулюють процеси транскрипції, трансляції та активності білків, впливаючи таким чином на щоденні зміни індивідуальної фізіології та поведінки. Однак донедавна впливи циркадних ритмів та сну на молекулярні механізми у клітинах головного мозку залишалися недостатньо зрозумілими. Авторами нової роботи отримано докази того, що саме цикли сну - неспання відіграють центральну роль у часовій регуляції багатьох аспектів синаптичних функцій.
Для комплексного аналізу ритмів фосфорилювання білків у синаптичному компартменті, які зумовлені циркадними та сонзалежними сигналами, на біохімічному рівні здійснено біохімічну ізоляцію синаптонейросом переднього мозку лабораторних тварин in vivo. У подальшому для оцінки добової динаміки фосфорилювання було застосовано методикількісної протеоміки на основі мас-спектрометрії. У результаті вченим вдалося дослідити формування синаптичного протеому та фосфопротеому протягом доби, а також оцінити вплив на ці процеси депривації сну. Так, в одному з досліджень було встановлено, що за фізіологічних умов, наближених до природних ритмів життя дослідних тварин, близько 25\% 38000 фосфорилювань синаптичних протеїнів у більшості важливих синапсів коливається, формуючи два основні піки активності: один - напередодні пробудження тварини, другий - безпосередньо перед ії засинанням.

Водночас у паралельному дослідженні, проведеному групою вчених Цюріхського університету, встановлено, що вміст синаптичних білків також зумовлений ритмікою циклічних процесів сну та пробудження. Зокрема, продемонстровано, що синаптична активність виступає тригером циклічного синтезу протеїнів із молекулмесенджерів, ритмічне накопичення яких відбувається протягомдня. Також автори акцентували увагу на процесах переміщення і накопичення молекул-месенджерів у синапсах переважно у відповідь на циркадні коливання, в той час як синтез білків повною мірою залежить від циклів сну та пробудження.

\section{Практичні висновки}

Підсумовуючи результати проведеного дослідження, науковці висловили впевненість у тому, що синаптичне фосфорилювання має вирішальне значення в регуляції синаптичних функцій, зокрема на етапах переходу від сну до пробудження. Натомість автори наголосили на негативній ролі депривації сну, яка сприяє майже абсолютній руйнації природних індивідуальних ритмів фосфорилювання синаптичних білків. Основне клінічне значення експериментальної роботи вчені вбачають в отриманні переконливих доказів того, що ключові синаптичні процеси, які контролюють безліч нейрональних мереж, включаючи процеси адаптації до змін та нейропластичності, регулюються у часі динамікою фосфорилювання протеїнів у відповідь на чергування циклів сну та неспання. Загалом же ж, на думку авторів, поглиблене розуміння природної ритміки фосфорилювання синаптичних протеїнів на системному рівні може мати вирішальне значення для оцінки порушень міжнейронної передачі в умовах патології, а отже - і для доказового пояснення ролі біоритмічних змін у розвитку поширених захворювань центральної нервової системи.

Brüning F., Noya S.B., Bange T. et al. (2019) Sleep-wake cycles drive daily dynamics of synaptic phosphorylation. Science, Oct. 11. DOI: 10.1126/science. aav3617.

Noya S.B., Colameo D., Brüning F. et al. (2019) The forebrain synaptic transcriptome is organized by clocks, but its proteome is organized by sleep. Science, Oct. 11. DOI: 10.1126/science.aav2642.

Наталія Савельєва-Кулик 